\title{
Technology Capability Model for Innovation Management for Fast Moving Consumer Goods Products (FMCG) Enterprises
}

\author{
Cezar Honorato (cezarhonorato@ita.br) - Departamento de Gestão Tecnológica, Instituto \\ Tecnológico de Aeronáutica (ITA). \\ Francisco Cristóvão Lourenço de Melo (ranciscofclm@,fab.mil.br) - Departamento de Gestão \\ Tecnológica, Instituto de Aeronáutica e Espaço (IAE).
}

\begin{abstract}
As globalization the competition between companies increasingly demands their ability to stay ahead of their competitors who are located far beyond their city, region or country and innovation has become essential for organizations not only to be leaders in their markets, but also to increase competitiveness and, above all, avoid its decline, a world-class innovation management process being vital. The objective of this article is to present a model of technological capacity accumulation for the management of innovation aimed at Fast Moving Consumer Goods Products (FMCG) enterprises. Through the participation of seventy-five professionals who work, directly or indirectly, in the development of innovations, a technological capability model was developed, consisting of seven levels of complexity, being references from the most basic to advanced levels so that organizations can measure themselves, compare with others and, through planning, to achieve excellence, which are broken down into five technological functions covered: investments, processes and production organization, equipment, activities related to products and innovation management.
\end{abstract}

Keywords: innovation; innovation management; innovation capability; technological accumulation. 


\section{INTRODUCTION}

The need for greater assertiveness in the launch of innovation products depends fundamentally on three factors: product focus, external analysis (supported by market analysis) and the firm's internal focus, these three pillars are critical to the successful launch of new products as they become available on the market.

With globalization, many companies that were based on an uncompetitive market had to adapt to competition based on global levels. Nowadays, it is imperative that innovations reach the objectives that have been planned, since a new product requires too much resource allocation, in multidisciplinary areas such as Marketing, R\&D, manufacturing, engineering, logistics and distribution, in all stages of a new development from the opportunity identification, market mapping, product development, to production and distribution. The movement of the whole chain without the result achieved generates great financial and resources losses for the organizations. In some cases, because the product has sales performance much lower than planned, it also has to absorb the cost of innovation discontinuity beyond the loss of packaging materials, product, publicity material and advertising that are always specific to new products.

De Negri et al. (2005) in a survey carried out with 72,000 Brazilian companies in conjunction with the Institute of Research and Applied Economics of Brazil, which had the unprecedented database articulation for the Brazilian industry with a focus on innovations, technological standards, performance and their competitive strategies rather than the traditional vision of size and industry demonstrate that innovating and differentiating products is extremely beneficial to companies and their employees.

In the study the companies were allocated in 3 categories: those that innovate and differentiate products, those that are specialized in standardized products with high productivity and those that do not differentiate and have lower productivity.

The table 1 demonstrates the consolidation of some results, being that companies that innovate and differentiate products, despite representing a smaller number (1.7\% of the total), accounted for $25.9 \%$ of industrial sales, accounting for $13.2 \%$ of the employment generated. The data show that the scale of production of firms that innovate and differentiate products is significantly higher than the other categories, average turnover of these companies is R $\$ 135.5$ 
million, which represents more than five times the average sales of specialized companies in standardized products. In firms that innovate and differentiate products, each employed person accounts for $\mathrm{R} \$ 74.1$ thousand of value added in production, representing $67.3 \%$ more than a worker from the specialized companies in standardized products, which produces, on average, $\mathrm{R} \$ 44.3$ thousand. The average remuneration is $\mathrm{R} \$ 1,254.64$ and the average education of its employees is of 9.13 years, also with a longer time of employment of 54.09 months when compared with the others and finally showed that innovation is positively correlated with exports in which the average value of the firms that innovate and differentiate products is on average much more than the other exporting companies.

This study also showed that if enterprises are exactly the same except for presenting different competitive strategies, those that innovate and differentiate products remunerate employees $23 \%$ more than those who do not differentiate products and have lower productivity, and $11 \%$ more than those specializing in standardized products.

TABLE 1 - Comparison of Brazilian industry indicators according to competitive strategies. Source: De Negri et al. (2005).

\begin{tabular}{|c|c|c|c|c|c|c|c|c|c|c|c|}
\hline Competitive Strategy & $\begin{array}{c}\text { Number } \\
\text { of } \\
\text { the } \\
\text { companies }\end{array}$ & $\begin{array}{l}\text { Participation in } \\
\text { earnings of } \\
\text { Industry } \\
(\%)\end{array}$ & $\begin{array}{l}\text { Participation } \\
\text { in } \\
\text { employment } \\
(\%)\end{array}$ & $\begin{array}{c}\text { Average } \\
\text { billing } \\
\text { (RSS million) }\end{array}$ & $\begin{array}{c}\text { Worker } \\
\text { Productivity } \\
\left(\mathbb{R} \${ }^{*} 1000\right)\end{array}$ & $\begin{array}{c}\text { Average } \\
\text { Remuneration } \\
\text { (RȘ/month) }\end{array}$ & $\begin{array}{l}\text { Average } \\
\text { Education } \\
\text { (years) }\end{array}$ & $\begin{array}{l}\text { Average } \\
\text { working } \\
\text { time } \\
\text { (months) }\end{array}$ & $\begin{array}{c}\text { Salary } \\
\text { award } \\
(\%)\end{array}$ & $\begin{array}{l}\text { Average } \\
\text { value } \\
\text { Exports } \\
\text { US\$ } \\
\text { million }\end{array}$ & $\begin{array}{l}\text { Average } \\
\text { value } \\
\text { Imports } \\
\text { Us\$ } \\
\text { million }\end{array}$ \\
\hline Innovate and differentiate products & $\begin{array}{r}1.199 \\
(1,7 \%) \\
\end{array}$ & 25,9 & 13,2 & 135,5 & 74,1 & $1.254,64$ & 9,13 & 54,09 & 23 & 11,4 & 12,01 \\
\hline Specializing in standardized products & $\begin{array}{r}15311 \\
(21,3 \%) \\
\end{array}$ & 62,6 & 48,7 & 25,7 & 44,3 & 749,02 & 7,64 & 43,9 & 11 & 2,1 & 1,8 \\
\hline $\begin{array}{l}\text { Don't differentiate products and } \\
\text { lower productivity }\end{array}$ & $\begin{array}{r}55.495 \\
\quad(77,1 \%) \\
\end{array}$ & 11,5 & 38,2 & 1,3 & 10 & 431,15 & 6,89 & 35,41 & 0 & 0 & 0,0024 \\
\hline Total & 72.005 & 100,0 & 100,0 & & & & & & & & \\
\hline
\end{tabular}

\section{THEORETICAL FRAMEWORK}

Bell and Pavitt (1993, 1995) formulated a broad definition according to which technological capability (TC) incorporates the resources needed to generate and manage technological change. Figueiredo (2005) complements that such resources accumulate and are incorporated to individuals (such as aptitudes, knowledge and experience) and to organizational systems 
which led to the four-dimensional perspective on the concept: physical system, organizational system, individuals' minds and finally products and services.

Literature research demonstrates the efforts made to develop a model in which the TC of a company are categorized by functions, such a model suggests that the accumulation takes place from the simpler categories to the more complex ones being always cumulative throughout its existence. This metric was developed by Lall (1992), later refined by Bell (1995) and finally adapted by Figueiredo (2001), who developed studies directed to the steel industry as to the rate of accumulation of TC.

The model proposed by Lall (1992), show in Fig.1, was the basis for an assessment of the accumulated degree of the TC of the organizations. It was developed with three degrees of complexity according to the formality and purpose of the technological efforts, considering investment, production and relationship dimensions with the economy, being:

- Basic level - capacities accumulated through the basic routines of the production activity, that is, by-doing mechanisms. Training is necessary for companies to keep operating.

- Intermediate Level - capabilities built through activities or efforts conducted on a more deliberate basis. This training enables companies to improve the execution of improvement of the technology in use. It consists of the ability to find solutions whose performance must be superior.

- Advanced Level - capabilities that represent a higher level, in which the company should not only do better, but mainly do different, evolve or create new technologies.

In this proposal Lall (1992) makes it possible to distinguish operational capability from innovative capability. Operational capability is considered synonymous with the expression know-how, which indicates that knowledge and experience are accumulated to use technologies transferred by other companies / sectors / markets; acquired by efforts by-doing - constitutes a technological capability of lower aggregate level of complexity. Innovative capability is understood as the knowledge, experiences and capacities to understand the principles of technology, and can be considered a synonym of the term know-why - its level of complexity is greater (Lall, 2000). 
13ํㅡㄹ Congresso Brasileiro de Inovação e Gestão de Desenvolvimento do Produto

08 a 10 de setembro de 2021 - Escola de Engenharia de São Carlos - Universidade de São Paulo

\begin{tabular}{|c|c|c|c|c|c|c|c|c|}
\hline & & & \multicolumn{6}{|c|}{ Functional Dimensions } \\
\hline & & & \multicolumn{2}{|c|}{ Investments } & \multicolumn{3}{|c|}{ Production } & \multirow{2}{*}{ Connect with other partnes } \\
\hline & & & Pre-investments & Project Execution & \begin{tabular}{|l|} 
Product Engineering \\
\end{tabular} & Process Engineering & Industrial Engineering & \\
\hline \multirow{7}{*}{ 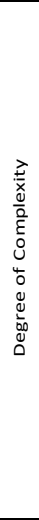 } & \multirow{4}{*}{$\begin{array}{l}\frac{u}{n} \\
\bar{n} \\
\infty\end{array}$} & \multirow{4}{*}{$\begin{array}{c}\text { Simple Routine } \\
\text { (based on experience) }\end{array}$} & $\begin{array}{l}\text { Technical-economic } \\
\text { feasibility study }\end{array}$ & Construction & Reverse Engineering & Quality Control & $\begin{array}{l}\text { Studies of working } \\
\text { methods and times }\end{array}$ & $\begin{array}{c}\begin{array}{c}\text { Local procurement of goods } \\
\text { and services }\end{array} \\
\end{array}$ \\
\hline & & & Local Selection & Auxiliary services & \multirow{3}{*}{$\begin{array}{c}\text { Minor adaptations to } \\
\text { market needs }\end{array}$} & $\begin{array}{c}\text { Preventove } \\
\text { Maintenance } \\
\end{array}$ & \multirow{3}{*}{ Inventory control } & \multirow{3}{*}{$\begin{array}{c}\text { Exchange of information with } \\
\text { suppliers }\end{array}$} \\
\hline & & & \multirow{2}{*}{ investment schedule } & $\begin{array}{l}\text { Equipment } \\
\text { installation } \\
\end{array}$ & & & & \\
\hline & & & & Commissioning & & assimilation & & \\
\hline & \multirow{2}{*}{ 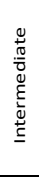 } & \multirow[b]{2}{*}{$\begin{array}{l}\text { Adaptive Duplicable } \\
\text { (search based) }\end{array}$} & $\begin{array}{l}\text { Technological source } \\
\text { search }\end{array}$ & $\begin{array}{l}\text { Equipment } \\
\text { purchase }\end{array}$ & $\begin{array}{c}\text { Product quality } \\
\text { improvement }\end{array}$ & $\begin{array}{l}\text { Licensing of new } \\
\text { technologies }\end{array}$ & Productivity monitoring & \begin{tabular}{|c|}
$\begin{array}{c}\text { Technology transfer from } \\
\text { local suppliers }\end{array}$ \\
\end{tabular} \\
\hline & & & $\begin{array}{c}\begin{array}{c}\text { Supplier contract } \\
\text { negotiation }\end{array} \\
\text { Information Systens } \\
\end{array}$ & $\begin{array}{l}\text { Detailing, } \\
\text { recruiting and } \\
\text { training the team }\end{array}$ & \begin{tabular}{|c|} 
Modification of \\
products purchased \\
through licensing
\end{tabular} & $\begin{array}{c}\text { Adaptation of processes } \\
\text { and cost reduction }\end{array}$ & $\begin{array}{l}\text { Improved process } \\
\text { coordination }\end{array}$ & $\begin{array}{r}\text { Relations with technology } \\
\text { and innovation institutions }\end{array}$ \\
\hline & 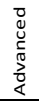 & $\begin{array}{c}\text { Innovative } \\
\text { (based on Research and } \\
\text { Development) }\end{array}$ & & $\begin{array}{l}\text { Basic process } \\
\text { design }\end{array}$ & $\begin{array}{c}\text { Product Innovation } \\
\text { In house }\end{array}$ & $\begin{array}{l}\text { Process Innovation } \\
\text { In house }\end{array}$ & & \begin{tabular}{|c} 
Licensing proprietary \\
technologies to third parties
\end{tabular} \\
\hline
\end{tabular}

FIGURE 1 - Lall's Technology Capabilities Matrix. Source: Gallina and Fleury (2013)

Already in the model developed by Bell (1997) and Figueiredo (2003) the development of the TC of the companies occurs in a process of accumulation over the years in a gradual trajectory of acquisition of new TC (fig. 2). The author divides his model into four levels of TC of companies from emerging economies in which it proposes levels of evolution for the types of technological competence over the years, in which over time it is expanding and adding the skills until reaching a level of maturation ranging from the simplest that is the level of simply using and operating technologies to the most advanced that means in developing and implementing new technologies.

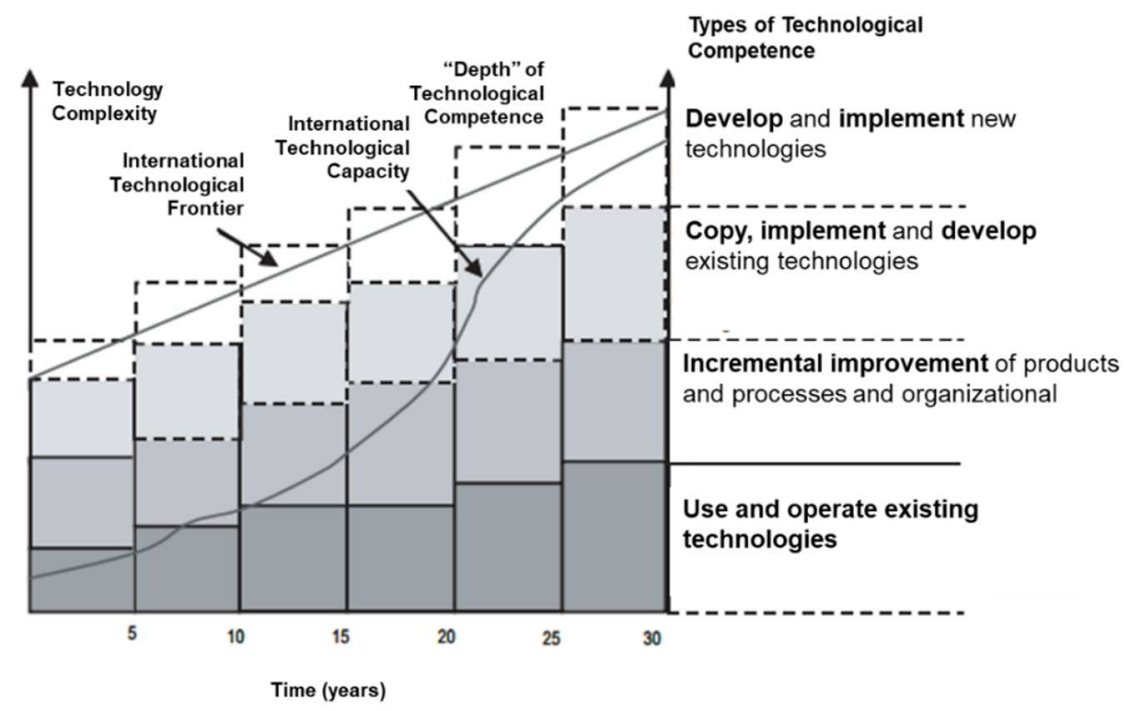

FIGURE 2 - Bell's Model. Source: Figueiredo (2005) 
The model proposed by Figueiredo (2003) allows us to measure the accumulation of TC based on activities that the company is able to carry out throughout its existence. It is possible to distinguish between routine capacities, the ability to use or operate certain technology, and capacities innovative, it is possible to adapt or develop the functions: new production processes, organizational systems, products, equipment and engineering projects, i.e., generate and manage technological innovation being world references, divided into seven levels of capability, the most basic (level 01) and the most advanced (level 07).

It is important to note that in this model capability levels are cumulative, so being at a given level means that there is a mastery of the requirements of previous levels. This model does not assume a linear sequence for evolution or that the capacities are constructed at the same time and at the same speed for the different functions.

Other researchers have also built descriptive accumulation models in stages, such as Sato and Fujita (2009), whose model considers the functions of planning, production and marketing. The planning functions include market research, development of the product concept, development of a new product according to market needs. Production was subdivided into related equipment functions: input processing operation, maintenance, design and production of equipment and machinery. Production management encompasses the organization of production activities efficiently to achieve the performance goal. Finally, Marketing focuses on designing market products that strengthen relationships with customers and explore new markets (Sato and Fujita, 2009).

\section{METHODOLOGY}

The research procedure used in this work can be divided into four distinct phases as shown in Figure 3. An initial phase creates a thorough understanding of the product development process fields through systematic literature search for a model structure. that is practical and applicable to the reality of industrial companies, phase 01 of bibliographic review is detailed in Figure 3.

In carrying out the extensive bibliographical research, the thematic keywords associated with this work were used as initial reference: Innovation, Innovation Management, Innovation Capacity and Technological Accumulation. 
To ensure academic relevance, we limited the bibliometric research of this work to the availability of full-text articles from peer-reviewed journals, containing online databases published in the last 5 years (2016-2020) in the Web of Science and Scopus databases. Figure 3 shows that four hundred and twenty-six documents were found, which were reviewed, including technical articles, government research and, when available, the most relevant citations and after analysis, the starting point was obtained, the bibliographical references used in this study, resulting in two hundred and thirty-four documents.

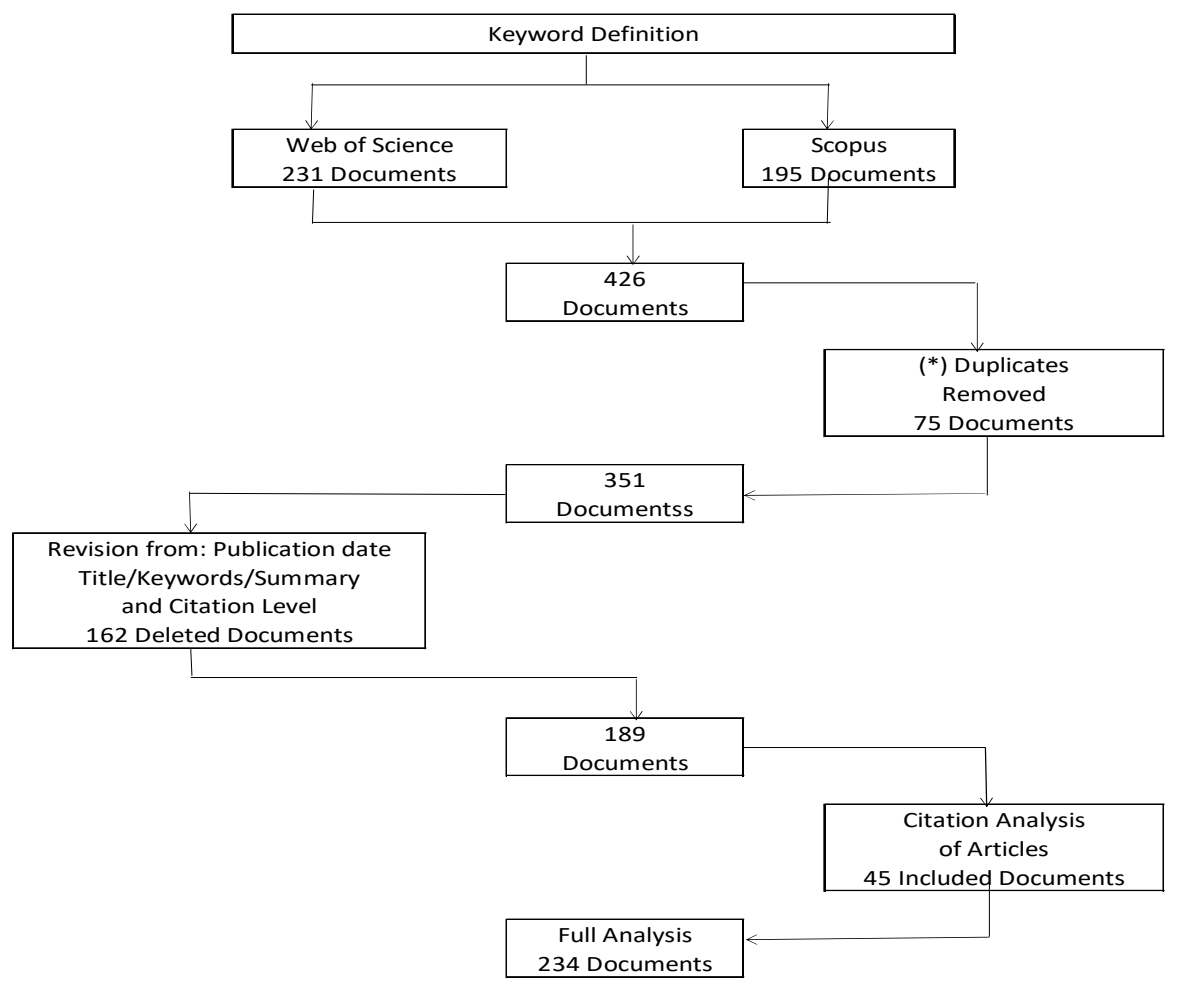

FIGURE 3 - Literature Review Process

As the theme of this research effort is multidisciplinary, the research of the theoretical framework provided the identification of the conceptual bases to be used and that will permeate all the work that identifies the second phase. The third phase is marked by an interview process with 75 professionals who work, directly or indirectly, with the product development process such as: Engineering, Quality, Research and Development, Project Management, Customer Support, Supplier Development with focus on two themes that involve product development processes directly in innovation management in practice: (i) Companies fail in their innovation 
processes with regard to the industrial sector in the development of products and/or processes, due to lack of capability or even of its results; and (ii) Companies do not assess their own resources in the process of developing innovations that prevent them from taking any coordinated action.

The next, and last, stage, the fourth phase, is the result of this research effort, presented in the next section, which is the definition of the model that this work proposes, which presents a model of technological accumulation capacity directed to activities related to the innovation management.

\section{RESULTS AND DISCUSSIONS}

According to the model proposed by Figueiredo (2003) with the objective of measuring of TC accumulation based on activities that the company is able to carry out throughout its existence is proposed by this paper the capability accumulation model for the innovation management function.

The model presents seven cumulative levels of innovation management capacity, classified according to the level of competence. They are: Level 1 - Basic, Level 2 - Renewed, Level 3 - Extra Basic, Level 4 - Pre-Intermediate, Level 5 - Intermediate, Level 6 - High Intermediate and Level 7 - Advanced.

The following is a summary of what is expected for each level according to the capacity accumulation model for the innovation management function proposed in this work. The details are shown in Figure 4. The classification is based on the analysis of following criteria: investments, market analysis, governance, product development process, process control, metrics, measurement and achievement of results, failure analysis and establishment of continuous improvement process for innovation management.

- Leve1 - Basic Routine:

It is at this level the company that launches the innovation without market analysis, without criteria, without established staff and without control of the deliveries. 
There is only one leader, and there is no formalized team for the development of project, which receives aid through cooperation.

There is a definition of the scope of innovation, represented by the product that must be delivered, but without specifying the specifications.

The initiatives are spread across areas of dispersed support in which actions are carried out according to the need and when they appear, therefore, without prior analysis or even planning. There is no priority analysis of the most important activities, as well as the most relevant projects.

- Level 2 - Renewed Routine:

At this level, the company is launching the innovation with market analysis based on the experience of the professionals who work in it, therefore without research support.

The technological functions are based on a solid routine centered on the organization's internal management without extension when, at most, the internal borders of the companies are regionally extended, but without systematization.

There is a clear definition and specification of the product to be delivered. There is also a multifunctional team formalized for each innovation with defined responsibilities; however, there is no control of deliveries.

- Level 3 - Extra Basic Innovative:

The company that identifies the need for innovation based on qualitative research is at this level. It is able to define the scope of the project, mapping the main activities that involve the control of the time, with the support of a schedule, costs and the main risks involved.

Risk assessment is not limited to the development of the new product but also in the production and the sending to the market where the most relevant risks are identified and mitigation actions are planned and executed.

At this level are also defined the indicators that the innovation should deliver which gives clarity to the expectations of the project result. Can prioritize innovations according to the most relevant to your business through metrics. 
- Level 4 - Pre-intermediate Innovative:

At this level, the company identifies the need for innovation based on detailed quantitative research and performs portfolio management by prioritizing the most relevant initiatives, which will deliver the most advantageous benefits through available resources.

There is a defined system for the management of innovation, from the generation of the idea to the launch in the market. Such consistency is consistently followed.

There are details and specification of all materials used (raw material and packaging) as well as clearly established process map.

- Level 5 - Intermediate Innovative:

At this capacity level, clear and objective criteria are defined for the approval of innovation, aligned with the company's strategic planning goals, at least as regards financial return, quality and sales volume attainment.

The innovation management system involves the whole cycle of innovation, ranging from idea generation to market launching and, subsequently, product performance analysis in the market up to one year after its launch. There is a clear governance framework for portfolio management of innovation projects.

The necessary competencies are surveyed in order to develop them, or to improve them to support the delivery of innovation. There is the analysis and quality control of all the materials used for the production of the product (packaging and raw material) or the quality guarantee sent by the supplier for all batches of materials with the reports of analysis and approval. There is the evaluation of the quality by attributes of the products produced, which happens only at the end of the production process.

- Level 6 - Upper Intermediate Innovative: 
At this level is the company that manages innovation in a systemic way with clear metrics and with the measurement of results, but there is no consistent achievement of the planned indicators, at least as regards quality, financial return and sales volume attainment

Beyond absolving new technologies, there is active development being the main actor with global suppliers.

There is the establishment of the statistical control procedure throughout the assembly or production process with quality assessment by attributes through control and verification items, however there is no plan for systemic or punctual variations can be detected and corrected in their root causes.

- Level 7 - Advanced innovative:

A company at this level of innovation management performs the measurement and attainment of the results that were planned before the launch, at least as to the quality, financial return and reach of sales volume after one year of the product entering the market. The innovations that did not have the desired performance have through the methodology the identification of the root causes of the failures. We analyze the lessons learned so that improvements can be incorporated into future innovations so that the same mistakes are not repeated.

It is ensured that quality and consumer satisfaction indexes established within the firm are achieved through a continuous improvement methodology composed of consistent plans and results at a six-sigma level. Analysis tools are used that focus on process variations, nonspecification products and consumers complaints of the products launched

Figure 4 shows the breakdown of technological capacity levels for the five technological functions covered: investments, production processes and organization, equipment, activities related to products and innovation management. 


\begin{tabular}{|c|c|c|c|c|c|}
\hline \multicolumn{6}{|c|}{ Technological capability of FMCG Enterprises } \\
\hline \multirow{2}{*}{$\begin{array}{l}\begin{array}{c}\text { Technological } \\
\text { Competence } \\
\text { Levels }\end{array} \\
\end{array}$} & \multicolumn{5}{|c|}{ Technological Functions } \\
\hline & Investments & $\begin{array}{l}\text { Production processes and } \\
\text { organization } \\
\text { ROUTinES }\end{array}$ & Equipment & Product Related Activities & Innovation Management \\
\hline $\begin{array}{l}\text { (1) Basic } \\
\text { Routine }\end{array}$ & $\begin{array}{l}\text { Initial preparation of the project. } \\
\text { Synchronization of civil construction } \\
\text { work and facilities. }\end{array}$ & $\begin{array}{l}\text { Routine coordination in the plant and } \\
\text { Absorption of plant production capacity. }\end{array}$ & $\begin{array}{l}\text { Installation of production equipment with local } \\
\text { suppliers without selection/approval criteria. }\end{array}$ & $\begin{array}{l}\text { Quality control in the production process by } \\
\text { inspection by people dedicated b b the Quality } \\
\text { area. Consolidation of consumer complaint } \\
\text { results. }\end{array}$ & \begin{tabular}{|l|} 
Product definition, non-formalized team for \\
project development. Initiatives sprayed and \\
with dispersed support areas (no priority). New \\
product launches without market evaluation.
\end{tabular} \\
\hline $\begin{array}{l}\text { (2) Renewed } \\
\text { Routine }\end{array}$ & $\begin{array}{c}\text { Routine factory engineering services, } \\
\text { undetailed scope and uncontrolled lead } \\
\text { time. }\end{array}$ & \begin{tabular}{|c}
$\begin{array}{c}\text { Enhanced Factory Coordination. } \\
\text { Implementation of basic tools (5s, action } \\
\text { plan, Lupi, see and act) of quality. Use of } \\
\text { Computerized Sintema and Management. }\end{array}$ \\
\end{tabular} & $\begin{array}{l}\text { Installation of equipment for production with local } \\
\text { suppliers with criteria of selection / approval and } \\
\text { measurement of performance. }\end{array}$ & \begin{tabular}{|c|} 
Quality control systematically done by the \\
operators of each equipment with inmediate \\
corrective actions to correct deviations. Analysis of \\
the results of consumer complaints with the \\
preparation of actions of actions to eliminate the \\
causes.
\end{tabular} & $\begin{array}{c}\text { Multifunctional (matrix) team formalized for } \\
\text { each project with clear and direct support. } \\
\text { Prioritization of innovations by subjective } \\
\text { criteria ("feeling"). }\end{array}$ \\
\hline $\begin{array}{l}\text { (3) Extrabasic } \\
\text { Innovative }\end{array}$ & $\begin{array}{l}\text { Project planning. Study of financial } \\
\text { return viabioity and detaialed scope. } \\
\text { Gantt-only follow-up of major events } \\
\text { (not detailed). }\end{array}$ & $\begin{array}{l}\text { INNOVATIVE } \\
\text { Small adpaths and intermitends in } \\
\text { production processes in factories. } \\
\text { Consolidation of basic quality tools and } \\
\text { implementation of new management } \\
\text { techniques and advanced quality tools. } \\
\text { (TQM, green belt). }\end{array}$ & $\begin{array}{l}\text { Installation of equipment for production with local } \\
\text { suppliers with criteria of selection / approval and } \\
\text { measurement of performance with technical } \\
\text { maintenance supported by plant team. }\end{array}$ & $\begin{array}{l}\text { Quality control systematically done preventively } \\
\text { with the support of actions to eliminate the } \\
\text { frequent causes of deviation. Specific forums for } \\
\text { analysis of quality complaints (cCQ - Quality } \\
\text { Control Circle). }\end{array}$ & $\begin{array}{l}\text { Launch of new products based on qualitative } \\
\text { research. Financial study of raadwork to } \\
\text { support innovation. Detailed scope. }\end{array}$ \\
\hline $\begin{array}{l}\text { (4) Pre- } \\
\text { intermediate } \\
\text { Innovative }\end{array}$ & \begin{tabular}{|c|} 
Basic engineering in technically assisted \\
expansions with the technical team: \\
engineering, maintenance and \\
R\&D. Exception of projects supported by \\
a detailed time schedule.
\end{tabular} & $\begin{array}{c}\text { Systematic expansion of production } \\
\text { capacity. Use of tools to move safety from } \\
\text { work, environment and factory } \\
\text { performance. }\end{array}$ & $\begin{array}{l}\text { Installation of equipment for production with local } \\
\text { suppliers with criteria of selection / approval and } \\
\text { measurement of performance with preventive } \\
\text { maintenance supported by plant team and } \\
\text { autonomous maintenance. }\end{array}$ & $\begin{array}{l}\text { Quality control support through consistent PDCA } \\
\text { (quality improvement) plan associated with the } \\
\text { results of consumer complaints. }\end{array}$ & $\begin{array}{c}\text { Launch of new products based on qualitative } \\
\text { and quantitites. Prioritization of innovations } \\
\text { with subjective criteria. Flow defined. Product } \\
\text { detailing and packaging. }\end{array}$ \\
\hline $\begin{array}{l}\text { (5) Intermediary } \\
\text { Innovative }\end{array}$ & $\begin{array}{l}\text { Detailengineering for hiring support., } \\
\text { Technical assistance forecast, resource } \\
\text { analysis (internal and external). }\end{array}$ & $\begin{array}{l}\text { Continuous process improvement. } \\
\text { Implementation of integrated } \\
\text { management system for the entire } \\
\text { factory. Operator-independent } \\
\text { maintenance implementation. }\end{array}$ & $\begin{array}{l}\text { Installation of equipment for production with global } \\
\text { suppliers with criteria of selection / /approval and } \\
\text { measurement of performance with preventive } \\
\text { maintenance supported by plant team and } \\
\text { autonomous maintenance. }\end{array}$ & \begin{tabular}{|c|} 
Quality control support through consistent PDCA \\
Iqualitit Improvenent plann associated with the \\
results of consumer complaints supported by \\
internal and external stakekololders of the \\
production process.
\end{tabular} & \begin{tabular}{|l|} 
Launch of new products based on a marketing \\
plan and structured product planning. \\
Objective criteria for the approval of \\
innovation. Flow "innovation funnel" for \\
prioritization and evaluation through pre- \\
established criteria Detailing and control of \\
scope, time and cost of innovation.
\end{tabular} \\
\hline $\begin{array}{l}\text { (6) Upper } \\
\text { Intermediate } \\
\text { Innovative }\end{array}$ & $\begin{array}{c}\text { World-class engineering for investments. } \\
\text { New processes designed with Support } \\
\text { from R\&D and world-class suppliers. } \\
\text { Management of scope, schedule, cost, } \\
\text { time, stakholders and project } \\
\text { communication. Control over } \\
\text { investments. }\end{array}$ & $\begin{array}{l}\text { World-class engineering for investments. } \\
\text { New processes designed with Support } \\
\text { from R\&D and world-class suppliers. } \\
\text { Management of scope, schedule, cost, } \\
\text { time, stakholders and project } \\
\text { communication. Control over } \\
\text { investments. }\end{array}$ & $\begin{array}{l}\text { Installation of equipment with global suppliers with } \\
\text { support of tim technical areas / R\&D with criteria of } \\
\text { selection / approval and measurement of } \\
\text { performance with preventive maintenance } \\
\text { supported by plant team and autonomous } \\
\text { maintenance by the operation. }\end{array}$ & 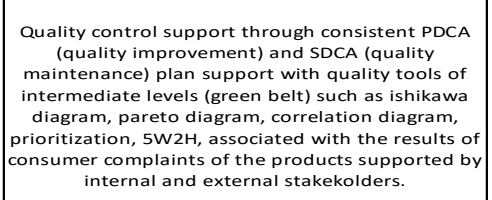 & $\begin{array}{l}\text { Launch of new products aligned with strategic } \\
\text { planning and supported by competencies. } \\
\text { Evaluation of the consistency of the delivery of } \\
\text { each invoagão compared to what was planned, } \\
\text { among them, financial result, achievement of } \\
\text { \% of sales (after } 1 \text { year of launch). }\end{array}$ \\
\hline $\begin{array}{l}\text { (7) Advanced } \\
\text { Innovative }\end{array}$ & $\begin{array}{c}\text { Evaluation of project consistency after } 1 \\
\text { year delivered: financial, qualitity } \\
\text { (deliveries made), lesson learning with } \\
\text { feedback in future projects. }\end{array}$ & $\begin{array}{c}\text { World-class production system. Reference } \\
\text { in design and development of new } \\
\text { porcessos supported by world-class R\&D } \\
\text { TIM. Stabilized improvement work at } \\
\text { sigma level 6. (black belt). }\end{array}$ & \begin{tabular}{|l} 
Installation of equipment for production with global \\
suppliers with support of technical red areas with \\
criteria of selection / approval and performance \\
measurement with achievement of $98 \%$ of the \\
agreed performance targets. Preventive \\
maintenance performed by the equipment operator.
\end{tabular} & \begin{tabular}{|c|} 
Quality control achieved at level 6 sigma result also \\
with the support of advanced quality tools (black \\
bult) such as: Map of aRtion, DOE \\
(Experimentation), (EVoP) Evolutionary Operation, \\
for fine tuning to reach the reliability of pr.96\% of \\
levels of acceptance of quality.
\end{tabular} & \begin{tabular}{|l|} 
Assertiveness of the achievement of targets \\
that support the launch of innovations above \\
99.96\% in $99.96 \%$ of projects (Level 6 sigma of \\
quality of innovations) through improvement \\
actions for the next projects based on the \\
"lessons learned" approved by the comitte and \\
incorporated into future innovations.
\end{tabular} \\
\hline
\end{tabular}

FIGURE 4 - Technological Capability Matrix for the FMCG Enterprises. Source: The authors 


\section{CONCLUSION}

From the objective placed in the focus of this work to measure the accumulation of technological capability (TC) eliminating the subjectivity that currently exists based on activities that the company is able to carry out throughout its existence was proposed the capability accumulation model for the innovation management.

The model suggests cumulative levels of innovation management capability from the most basic level (level 01) to the most advanced (level 07); with a broad view of innovation management the company has in this level is not restricted to have an established innovation process, but rather has clear metrics, established governance, results from innovation projects achieved, and failures that can happen will be analyzed under root causes process and implementation of the improvements identified in the next of the innovation projects.

The classification is based on the analysis of following criteria: investments, market analysis, governance, product development process, process control, metrics, measurement and achievement of results, failure analysis and establishment of continuous improvement process for innovation management.

The technological capability matrix is broken down into five functions, namely: investments, production processes and organization, equipment, activities related to products and innovation management.

The need to assess the level of innovation management capacity is a basic requirement for business continuity, it does not mean ease and simplicity in implementation, it requires a lot of discipline, focus and determination to avoid frequently proposed shortcuts that do not provide consistent results.

Finally, we emphasize that many companies fail to develop innovations throughout their existence with drastic consequences for the business and the model proposed in this research aims to provide a compass so that they can assess their skills and have a clear goal of achievements, such as future work aims to prepare a questionnaire to accurately assess and assess across companies, providing benchmarking references. 


\section{ACKNOWLEDGEMENTS}

This research effort was supported by National Counsel of Technological and Scientific Development (CNPQ) and Coordination for the Improvement of Higher Education Personnel (CAPES). We greatly thank for supporting this research.

\section{REFERENCES}

BELL, M. (1997). Overheads and notes on lectures and seminars (Technology and Development Course, MSc in Technology and Innovation Management Course). SPRU, University of Sussex.

BELL, M., \& PAVITT, K. (1993). Technological accumulation and industrial growth: contrasts between developed and developing countries. Industrial and corporate change, 2(2), 157-210.

BELL, M., \& PAVITT, K. (1995). The development of technological capabilities. Trade, technology and international competitiveness, 22(4831), 69-101.

De NEGRi, J. A. O., SAlERnO, M. S. O., AlMEIDA JÚNIOR, M. F. D., ALVES, P. F., ARAÚJO, R. D. D., ARBACHE, J. S., ... \& VIOTTI, E. B. (2005). Inovações, padrões tecnológicos e desempenho das firmas industriais brasileiras.

FIGUEIREDO, P. N. (2001). Technological learning and competitive performance. Edward Elgar Publishing.

FIGUEIREDO, P. N. (2003). Aprendizagem tecnológica e performance competitiva. Programa de pesquisa e aprendizagem tecnológica e inovação industrial. Revista de Administração Pública, Rio de Janeiro, 3(2), 323 361 .

FIGUEIREDO, P. N. (2005). Acumulação tecnológica e inovação industrial: conceitos, mensuração e evidências no Brasil. São Paulo em perspectiva, 19(1), 54-69.

GALLINA, R., \& FLEURY, A. (2013). A capacitação tecnológica na empresa: a função da Tecnologia Industrial Básica (TIB). Gestão \& Produção, 20 (2), 405-418.

LALL, S. (1992). Technological capabilities and industrialization. World development, 20(2), 165-186.

LALL, S. (2000). The Technological structure and performance of developing country manufactured exports, 1985-98. Oxford development studies, 28(3), 337-369.

SATO, Y., \& FUJITA, M. (2009). Capability matrix: a framework for analyzing capabilities in value chains. Inst. of Developing Economies, Japan External Trade Organization. 